\title{
Seasonal Variation of Fissile Particulate Materials in Atmospheric Deposits Collected in Niigata
}

\author{
Kaneaki Sato, Tetsuo Hashimoto*, Masayasu Noguchi, Tetsuya Sanada, \\ Shoji SATO and Tatemichi OKADA* \\ Japan Chemical Analysis Center \\ 295-3, Sanno-cho, Inage-ku, Chiba-shi 263-0002, Japan \\ ${ }^{*}$ Department of Chemistry, Faculty of Science, Niigata University \\ 8050, Ikarashinino-cho, Niigata-shi 950-2181, Japan
}

Received June 18, 1998

\begin{abstract}
Seasonal variations of fissile particulate materials, identified by fission track study, in monthly deposit collected in Niigata during 1985-1996 are presented. Probability of the month having larger number than the mean of monthly number of them varied with a tendency to be larger during December to April. In order to presume the origins of fissile particulate materials in deposit, ten stable elements in samples were determined by neutron activation analysis and the sizes of fissile particles were estimated by using a computer simulation. On the basis of these data, it was assumed that there were different origins of the fissile particulate materials such as soil near sampling site and Kosa dust.
\end{abstract} $\begin{aligned} \text { Key Words: } & \text { seasonal variation, fissile particulate material, atmospheric } \\ & \text { deposit, star-like fission track distribution, star FT, thermal } \\ & \text { neutron irradiation, instrumental neutron activation analysis, } \\ & \text { computer simulation }\end{aligned}$

\section{Introduction}

Because of the atmospheric and underground nuclear tests enforced until recent year, nuclear fission products such as ${ }^{137} \mathrm{Cs}$ or ${ }^{90} \mathrm{Sr}$ had been spread out into the worldwide environment. ${ }^{137} \mathrm{Cs}$ and ${ }^{90} \mathrm{Sr}$ are usually analyzed to monitor artificial radioactivity in the environment. Recently the monitoring data of environmental ${ }^{137} \mathrm{Cs}$ and ${ }^{90} \mathrm{Sr}$ have been utilized to discuss the transport and deposition mechanism of deposit ${ }^{1}$. It may be well accepted that the analysis of fissile particulate materials in deposit is also very important to study the transport mechanism. Hashimoto et al. reported the determination of fissile materials in giant particles (highly radioactive particles) as star-like fission track distribution (star FT) using a solidstate track detector, which is very useful to detect fissile materials such as ${ }^{235} \mathrm{U}$ or ${ }^{239} \mathrm{Pu}^{2), 3}$. In this paper we determined fissile particulate materials in deposit collected in Niigata, using the solidstate track detector, and discussed seasonal variations of the number of fissile particulate materials. In order to presume the origins of fissile particulate materials, some stable elements in the deposit samples were also analyzed by instrumental neutron activation analysis (INAA) and the particle sizes of fissile materials were estimated by a computer simulation of the star FT.

\section{Experimental}

\subsection{Collection and preparation of sample}

From 1985 to 1996 monthly deposits (precipitation and the deposited dust) were collected in a vessel set up on roof surface of a building (at about $15 \mathrm{~m}$ above the ground) of Niigata Univer- 
sity. After filtering the deposit with a Millipore filter paper (pore diameter of $0.45 \mu \mathrm{m}$ ), one fourth of the residue on the filter paper was used to detect fissile particulate materials, and another one fourth was used to determine some elements such as Al by INAA in some cases.

\section{$2 \cdot 2$ Fission track method}

One fourth of the residue collected on the Millipore filter paper was closely faced and fixed to a solid state track detector (Indian mica, No. 2, CSS grade), and irradiated by TRIGA-II reactor (Rikkyo University in Japan) to give thermal neutron fluence of about $3 \times 10^{16} \mathrm{~cm}^{-2}$, as shown in Table 1. After cooling for more than 1 month the track detector was chemically etched for 30 min with $35 \% \mathrm{HF}$ solution at $25^{\circ} \mathrm{C}$. Induced fission tracks were observed on the mica with an optical microscope. The star FT due to fissile particulate materials (a) or (b) and the homogeneously distributed fission tracks probably derived from materials with homogeneous and low uranium content (c) were recognized as shown in Fig. 1. The number of star FT $((a)+(b))$ and homogeneously distributed fission tracks were counted, respectively.

2.3 Determination of stable elements by instrumental neutron activation analysis (INAA)

Some stable elements such as $\mathrm{Al}$ or $\mathrm{Ca}$ in deposit samples (on the Millipore filter paper) collected monthly in 1988 and 1993 were analyzed by INAA. One fourth of the filter paper was sealed in a polyethylene bag and irradiated with JRR-3 M reactor (at Japan Atomic Energy Research Institute) or TRIGA- II reactor (at Rikkyo University). After cooling for decay out of short-lived nuclides, some elements of interest were determined by gamma-ray spectrometry using a Ge
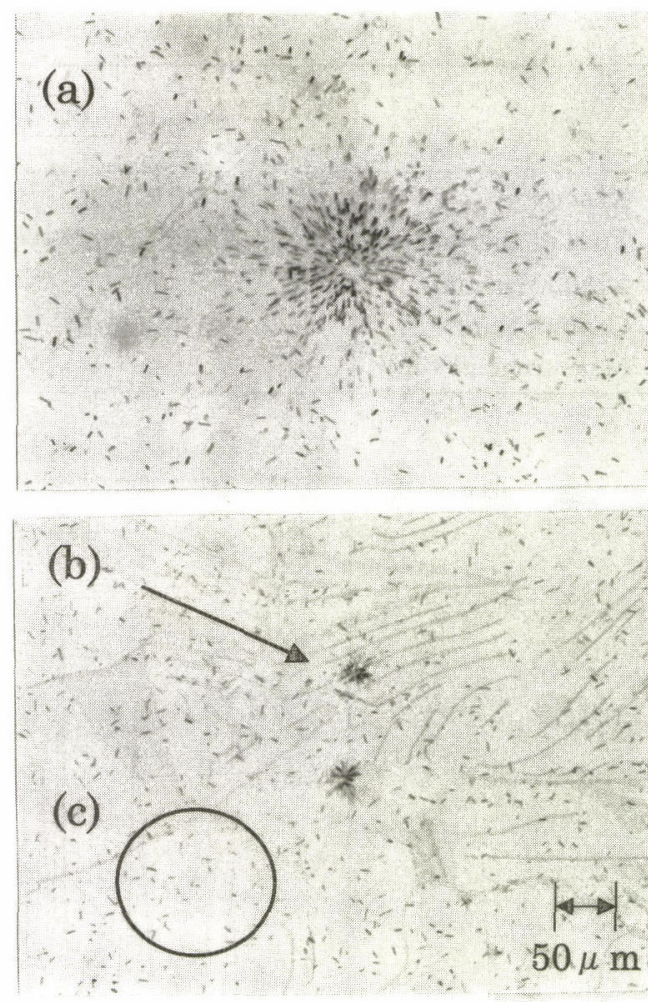

Fig. 1 Star FT due to fissile particulate materials (a), (b) and homogeneously distributed fission tracks due to materials with homogeneous and low uranium content (c).

detector. Conditions of neutron irradiation and radiation measurement are shown in Table 1.

\section{Results and Discussion}

$3 \cdot 1$ Seasonal variation of fissile materials in deposits

Time variation of the number of fissile particulate materials in deposits is shown in Fig. 2 (a). And Fig. 2 (b) shows the appearance probability of the month that has larger numbers than the mean of monthly number of star FT during 12 years from 1985 to 1996. For instance, the probability value of 0.64 in January is defined the ratio of number ( 7 times) of January, in which the number of star FT is larger than the mean of 
Table 1 Conditions of neutron irradiation and radiation measurement

\begin{tabular}{lcccc}
\hline & Fission track & \multicolumn{3}{c}{ INAA } \\
\cline { 3 - 5 } & & Mg Al Ca Ti & Mn & Na K Sc Fe Th U \\
\hline Reactor & TRIGA- II & & JRR-3M \\
Flux of thermal neutron & $1.5 \times 10^{12} \mathrm{n} \mathrm{cm}^{-2} \mathrm{~s}^{-1}$ & $1.9 \times 10^{13} \mathrm{n} \mathrm{cm}^{-2} \mathrm{~s}^{-1}$ & $5.0 \times 10^{13} \mathrm{n} \mathrm{cm}^{-2} \mathrm{~s}^{-1}$ \\
Irradiation time & $6 \mathrm{~h}$ & $50 \mathrm{~s}-1 \mathrm{~min}$ & & $30 \mathrm{~min}$ \\
Cooling time & $1-2$ month & $4-16 \mathrm{~min}$ & $1-2 \mathrm{~h}$ & $4-5$ day \\
Measurement time & - & $300 \mathrm{~s}$ & $100-300 \mathrm{~s}$ & $14000-15000 \mathrm{~s}$ \\
\hline
\end{tabular}
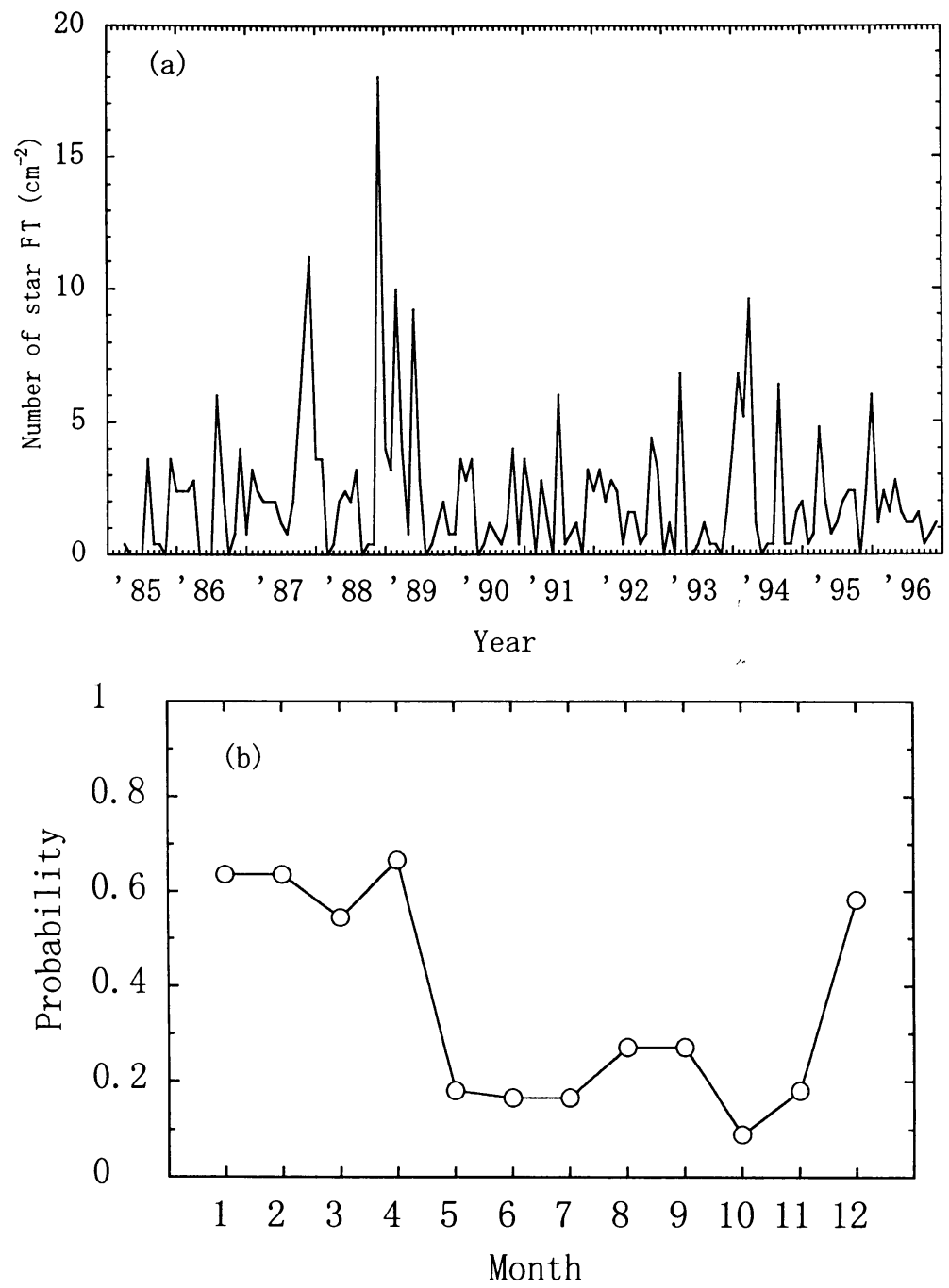

Fig. 2 Time variation of the number of star FT for 12 years (a) and probability of the month having higher number than the mean of monthly number of star FT (b). 
monthly number of star FT, to total number $(1986-1996,11$ years) of January; $(7 / 11=0.64)$. As shown in Fig. 2 (b), the number of star FT with a tendency to be higher during December to April. Taking the seasonal variation into consideration, detailed discussion is given below.

\subsection{Relation between the concentration of stable elements and the number of star FT}

$\mathrm{Al}, \mathrm{Fe}, \mathrm{K}, \mathrm{Mg}, \mathrm{Ca}, \mathrm{Na}, \mathrm{Ti}, \mathrm{Mn}, \mathrm{Sc}, \mathrm{Th}$ and $\mathrm{U}$ in the deposits were analyzed by INAA. The results of INAA are presented in Fig. 3 for samples collected in 1988 and 1993. Uranium in samples could be scarcely detected, because the detection limit of INAA under the present analytical condition is about $0.003 \mu \mathrm{g}$ per sample. Contents of other elements except $U$ showed the similar pattern of seasonal variation that had the maximum concentration of the elements during February to April. The elements in deposits have mainly three origins of soil, industrial dust and sea salt. The main origin of $\mathrm{Al}, \mathrm{Ca}$ and $\mathrm{Sc}$ are soil, and especially $\mathrm{Al}$ is typical of soil origin ${ }^{4)}$. Thorium is also from soil. To confirm both origins of $\mathrm{Al}$ and $\mathrm{Th}$ attributable to soil, the concentrations of $\mathrm{Al}$ were plotted versus Th ones as shown in Fig. 4. There was a good linear relationship between concentrations of $\mathrm{Al}$ and $\mathrm{Th}$. The concentration of uranium in deposits is important to examine whether the origin of star FT is uranium in soil or not. Upon this, we obtained a relative concentration of uranium (homogeneously distributed fission tracks (c) in Fig. 1) in the same samples in which star FT were observed. If the number of the homogeneously distributed fission tracks is related with concentration of $\mathrm{Al}$, almost all the homogeneously distributed fission tracks would be responsible to naturally existing uranium $\left({ }^{235} \mathrm{U}\right)$ in soil. As shown in Fig. 5, there was a linear rela-
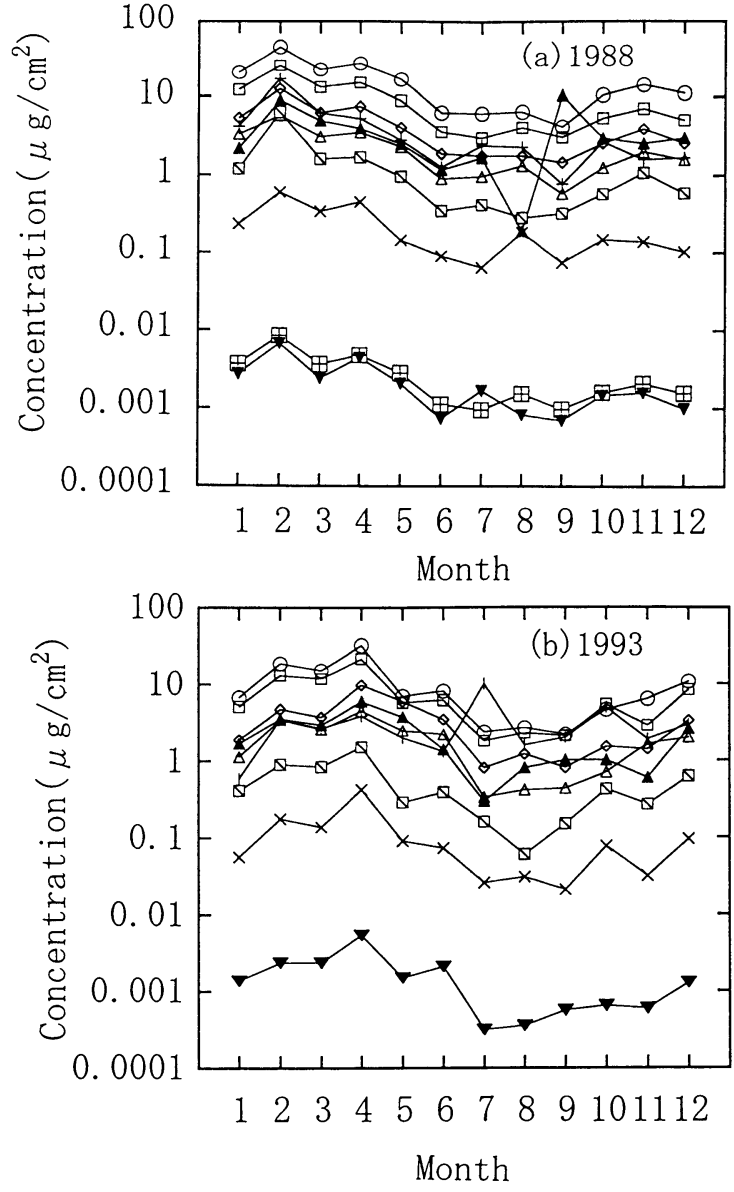

Fig. 3 Results of INAA for deposits in 1988 (a) and 1993 (b).

$$
\begin{array}{ll}
-\mathrm{Al} & -\mathrm{Na} \\
\square \mathrm{Fe} & -\mathrm{Ti} \\
\because \mathrm{K} & \rightarrow \mathrm{Mn} \\
\because \mathrm{Mg} & \rightarrow \mathrm{Sc} \\
-\mathrm{Ca} & \rightarrow \mathrm{Th}
\end{array}
$$

tion between the number of homogeneously distributed fission tracks and concentration of $\mathrm{Al}$. Figure 6 shows plots of the number of star FT versus homogeneously distributed fission tracks during $1985-1996$. As shown in Fig. 6, there is no relation between uranium contents and the number of fissile particulate materials in deposits. If the origin of star FT is soil, the number of them should be related with elements typically existing in soil such as $\mathrm{U}$ or $\mathrm{Al}$. It cannot be asserted that 


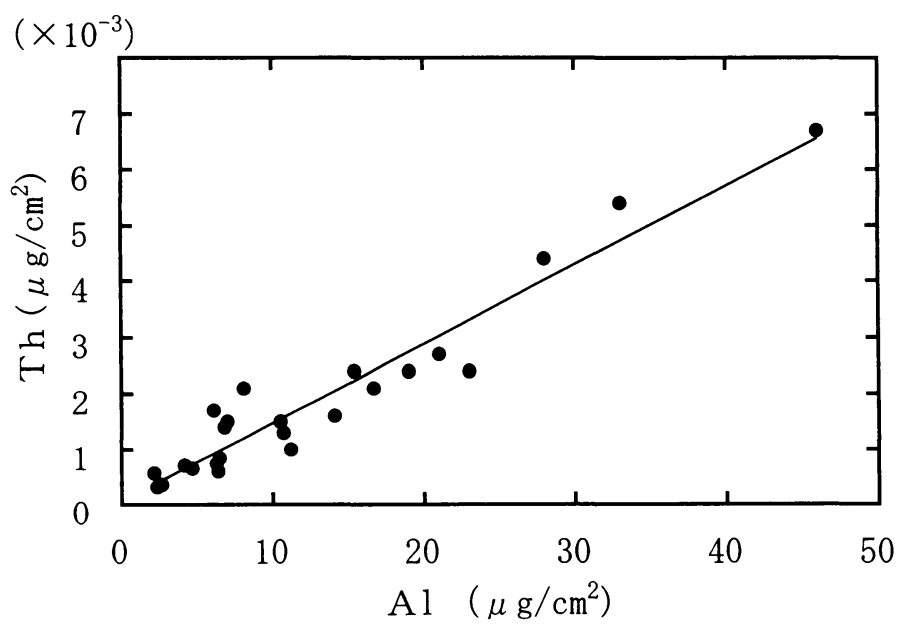

Fig. 4 Relationship between concentrations of $\mathrm{Al}$ and $\mathrm{Th}$ in monthly deposits in 1998 and 1993.

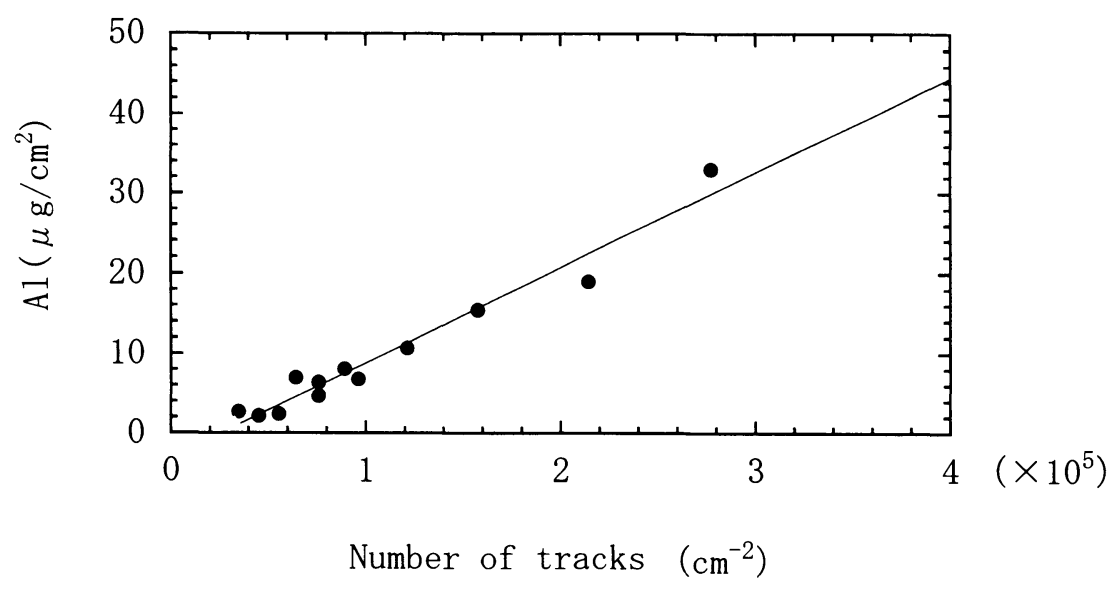

Fig. 5 Relationship between the number of homogeneously distributed fission tracks and concentration of $\mathrm{Al}$ in deposits in 1993.

the origin of star FT is a soil. Accordingly, other origins should be considered in addition to contribution of soil origin. It was reported that one of the origins of resuspended radioactivity in deposit might be the influence of the Kosa phenomena ${ }^{1), 5}$. Thereupon we thought about the influence of the Kosa (Chinese loess). It seems that Kosa phenomena are usually observed in spring, especially April, in Japan ${ }^{6}$. The seasonal variation of the number of star FT is a little similar to that of transportation of Kosa dust from China to Japan. One of the origins of Kosa is the Takla Makan Desert in China. Lop Nor $\left(40^{\circ} \mathrm{N}, 90^{\circ} \mathrm{E}\right)$ district, where nuclear tests had been enforced, is close to the desert ${ }^{7}$. Then, to examine the possibility that Kosa is a cause of the seasonal variation of number of star FT, the particle sizes of fissile particulate materials were studied by comparing with a computer simulation. 


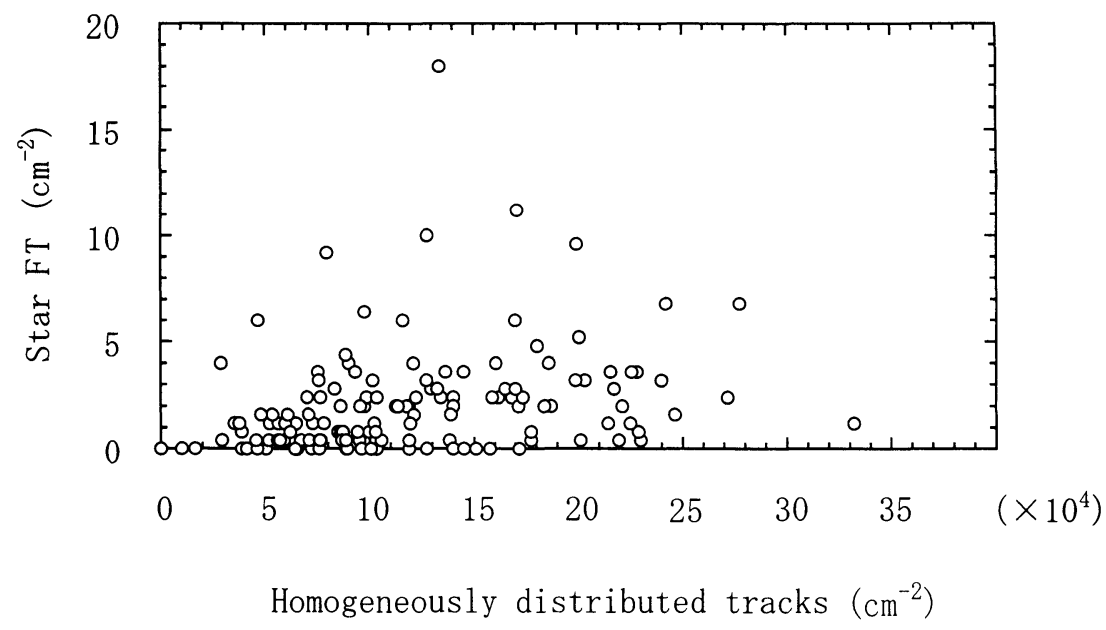

Fig. 6 Plots of the number of star FT vs. homogeneously distributed fission tracks during 1985-1996.

3.3 Particle size estimation by comparing with a computer simulation

To estimate the size of fissile particulate materials, a computer simulation was applied to the star FT. Physical parameters, shown in Fig. 7, were used to simulate the diameter of fissile particulate materials with the following assumptions including correction of self-absorption.

(1) The shape of the particle is spherical.

( 2 ) The initial kinetic energy of fission products (FPs) is $93 \mathrm{MeV}$; mean energies are $80 \mathrm{MeV}$ for heavy group FPs and $105 \mathrm{MeV}$ for light group $\mathrm{FPs}^{8)}$.

( 3 ) Stopping power of FP is independent of energy. The stopping power $(-\mathrm{d} E / \mathrm{d} X)$ of FP in mica is $8.5 \mathrm{MeV} / \mu \mathrm{m}$ that was calculated as an average value for light and heavy group FPs using the most probable range ${ }^{9)}$ of $11 \mu \mathrm{m}$. The stopping power in silica was assumed to be about $7.5 \mathrm{MeV} /$ $\mu \mathrm{m}$ as an average value for light and heavy group FPs, which were calculated using the data of range in different materials ${ }^{10)}$.

(4) Absorption in air, estimated to be thinner than $0.01 \mathrm{mg} / \mathrm{cm}^{2}$, between a sample and a mica is negligible, because the range in nitrogen

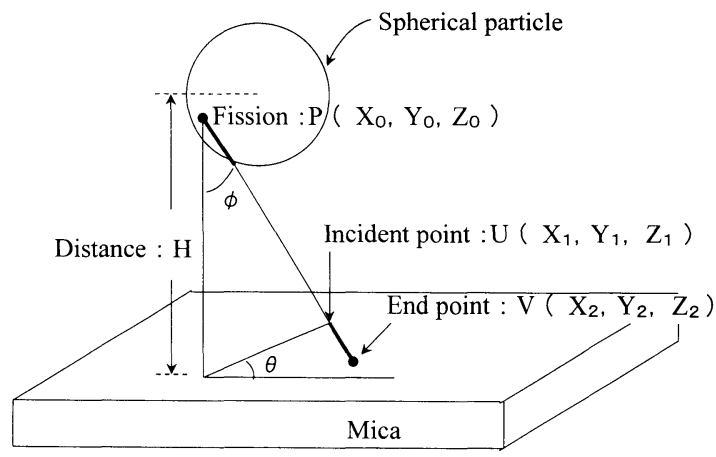

Fig. 7 Physical parameters for computer simulation.

gas is about $1.5 \mathrm{mg} / \mathrm{cm}^{211)}$.

Each symbol in the figure is;

$\mathbf{P}$ : position of fission in a spherical particulate material

$\mathrm{U}$ : incident point of FP on mica

$\mathrm{V}$ : end point of FP in mica

$\theta$ : emission angle of FP for radial direction

$\phi$ : emission angle of FP for axial direction

Figure 8 shows an example of star FT obtained with a computer simulation. Figure 9 shows a relation of particle diameter and position of the peak, which has the highest counts in a concentric area as shown in Fig. 8. As shown in Fig. 9, the 


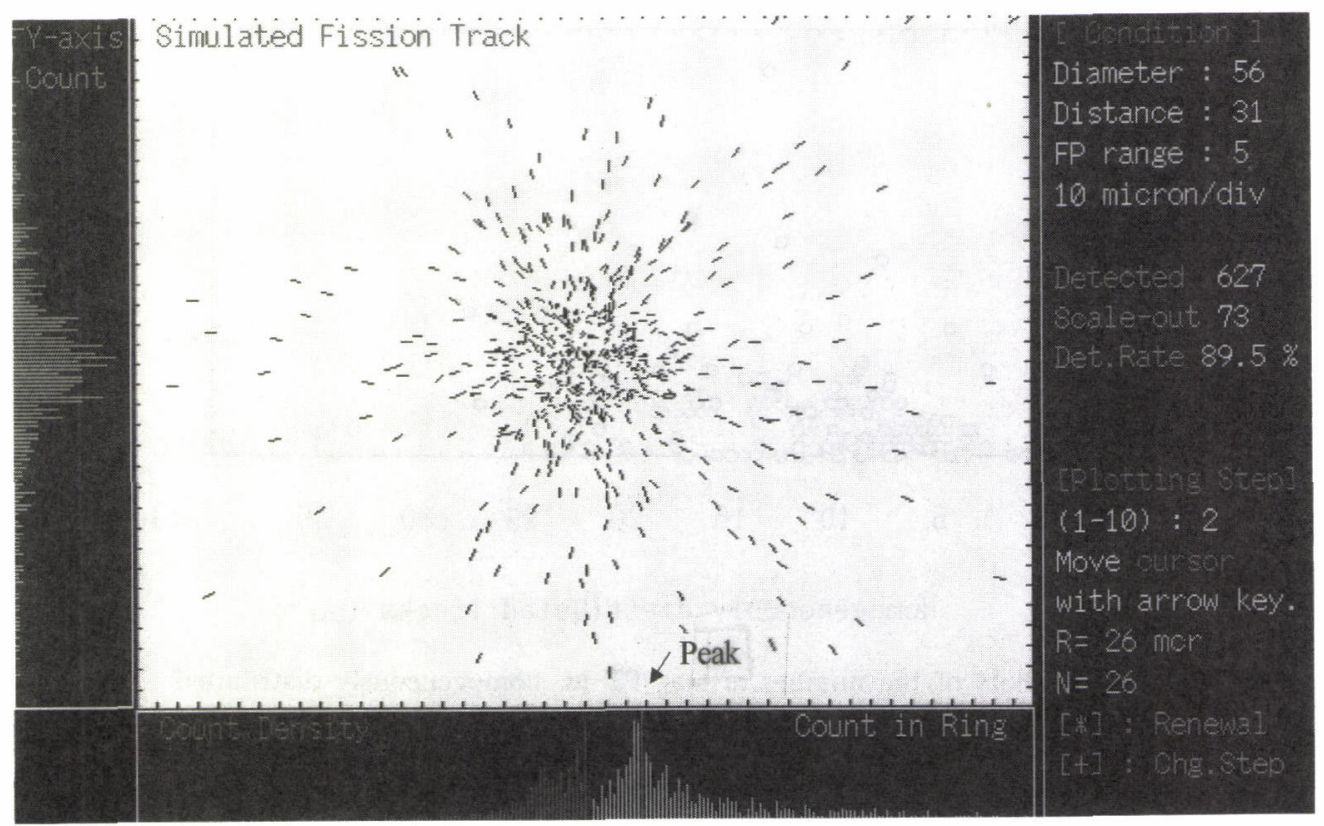

Fig. 8 An example of star FT obtained with a computer simulation.

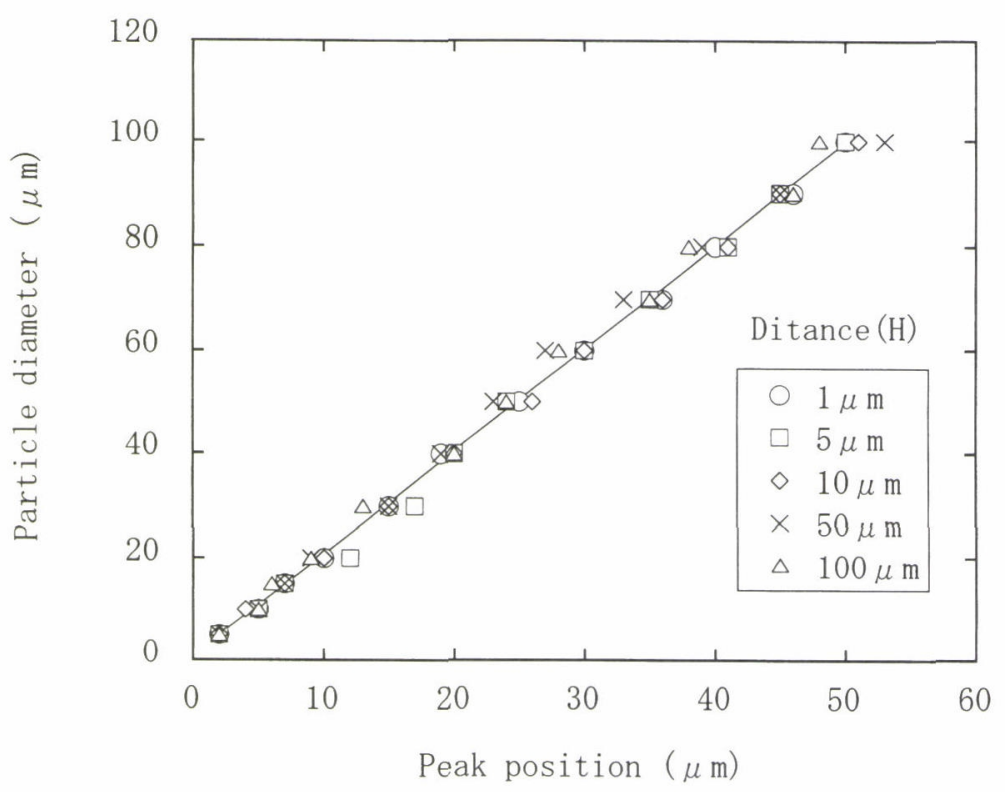

Fig. 9 Correlation between the peak position of track distribution in Fig. 8 and the particle diameter.

particle diameter correlates fairly well with position of the peak, irrespective of the distance between particle and mica. Therefore, we can estimate the particle diameter by counting tracks in each concentric area and using the relation as shown in Fig. 9. Figure 10 shows plots of number of fission tracks in a concentric area versus distance from the center of star FT to the incident 


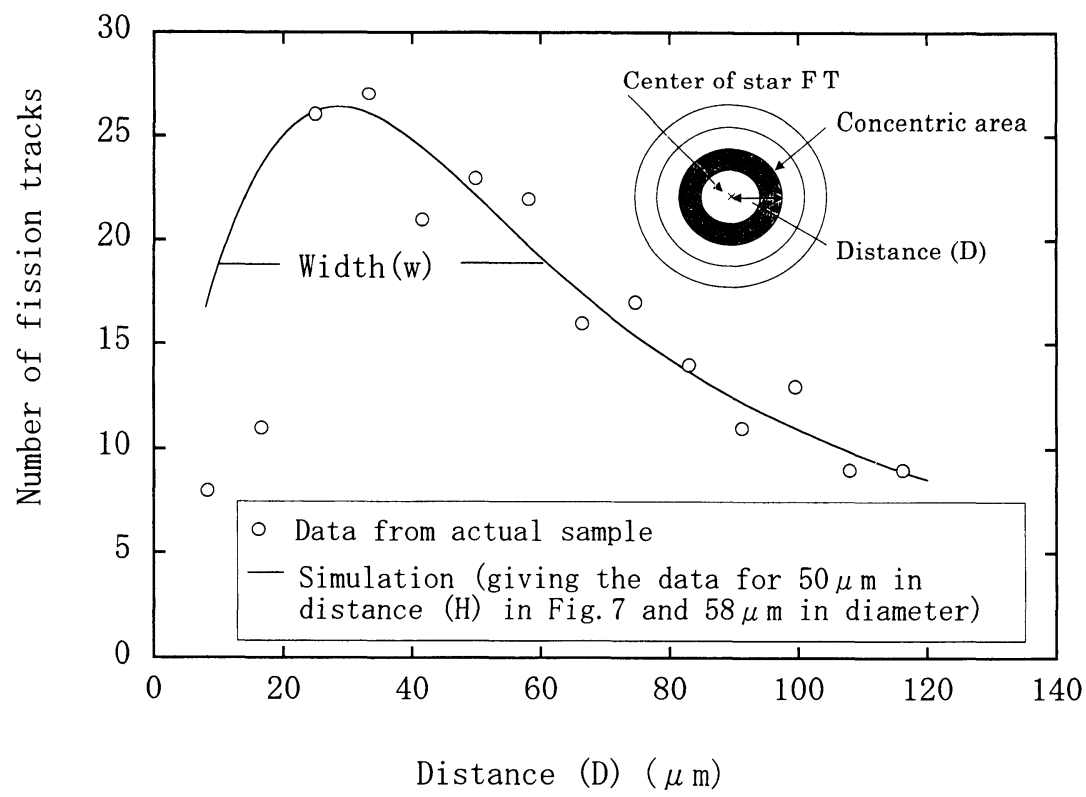

Fig. 10 Plots of number of fission tracks vs. distance (D) from the center of star FT to the incident point on mica.

point on mica, and the solid line obtained with the computer simulation. The width $(W)$ in Fig. 10 is related to the distance $(H)$ in Fig. 7. As shown in Fig. 10, the simulation reproduced well star FT. However, we can't estimate the particle diameter using this computer simulation on account of difficult track counting or larger statistical errors when the density of tracks is too dense or too thin. In those cases the time of neutron irradiation should be changed so that the track density is approximately $30000 / \mathrm{mm}^{2}$ at the highest counts in a concentric area. The diameters of some fissile particulate materials were estimated to be several ten $\mu \mathrm{m}$ by comparison with the simulation. Many star FT from fissile particles smaller than several ten $\mu \mathrm{m}$ were also observed (small star FT (b) in Fig. 1), but it was difficult to estimate their diameter for the reasons that the length (about $11 \mu \mathrm{m}$ ) of fission tracks on mica is too long compared to particle diameter and the number of tracks was too small.
3.4 Estimated origin of fissile particulate materials in deposit

Star FT can be observed in usual fission track patterns obtained with zircon or apatite having high contents of uranium ${ }^{12}$. Figure 11 (a) shows the fission track pattern obtained with zircon. A soil sample having high contents of uranium was separated into two fractions with the heavy liquid prepared by disolving $82 \%$ sodium polytungstate in water (specific gravity of 2.8 ), while the specific gravity of zircon and apatite are $4.66-4.7$ and $3.1-3.35$, respectively. After mixing well the soil in the heavy liquid the solution was centrifuged at $3.000 \mathrm{rpm}$ for $10 \mathrm{~min}$ to separate into the sunk and the floated fractions. Then these fractions were irradiated with thermal neutrons in the same as described above. Figure 11 (b) and (c) show the fission track patterns of the floated and the sunk fraction, respectively. We confirmed that there are many fissile particulate materials in the sunk fraction. From our experiments, as menti- 

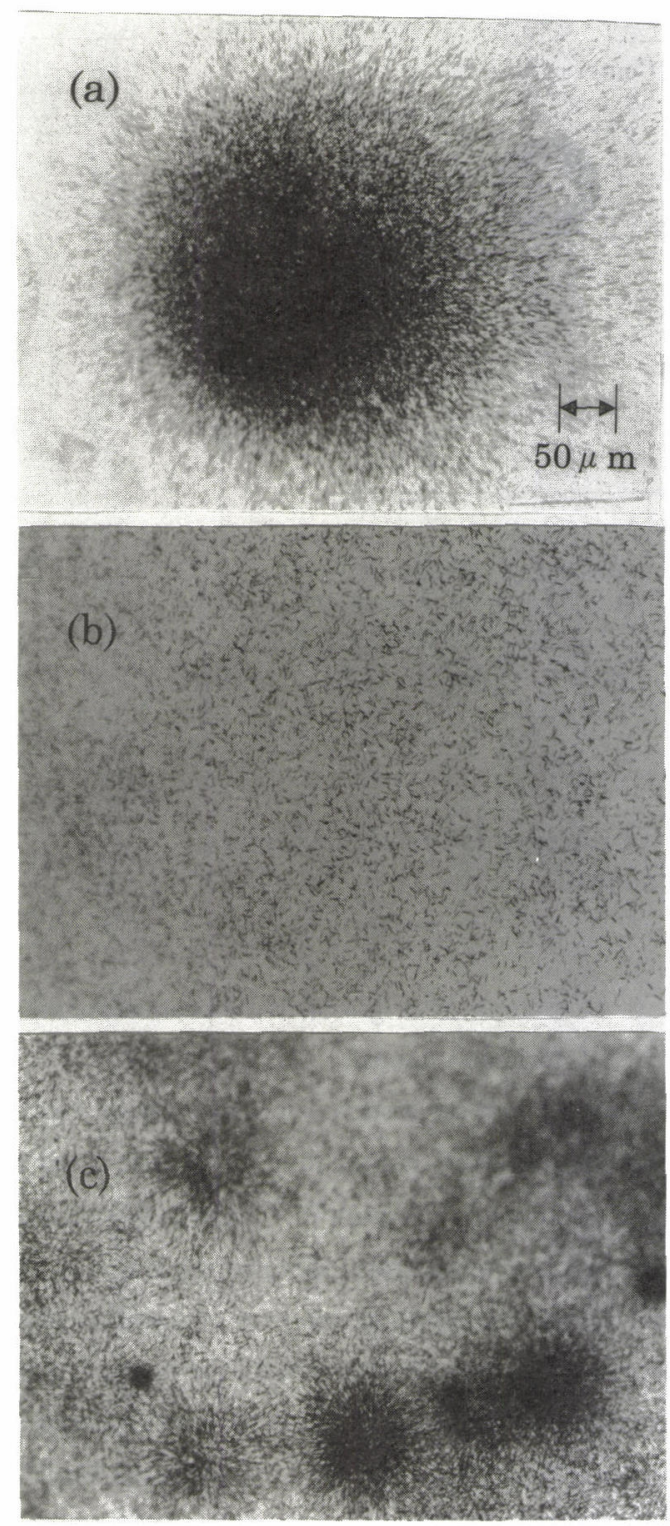

Fig. 11 Fission track from zircon (a), the floated fraction (b) and the sunk fraction (c).

oned above, it could not be clarified that the origin of almost all fissile particulate materials in deposited sample is soil, because the ratio of the number of homogeneously distributed fission tracks to star FT gives non-correlation in each other as shown in Fig. 6. As a result, we thought tentatively about the influence of fissile materials remaining in the environment as unfissioned fractions of the nuclear bomb. Hashimoto et al. reported that remnant hot particles in rainfalls and snowfalls, caused by the 19th Chinese nuclear explosion test in 1976, were spherical form having approximately $10 \mu \mathrm{m}$ diameter and many particles existed in ferromagnetic fraction and sunk fraction $^{13)}$. Since the particle diameters of Kosa dust and fallout debris from the nuclear test in atmosphere are estimated to be around $4 \mu \mathrm{m}^{6), 14)}$ and $25 \mu \mathrm{m}^{15)}$ at the most, the diameters of fissile particle estimated by the computer simulation, several ten $\mu \mathrm{m}$, are too large than those of Kosa dust or fallout debris. Presumably the origin of large fissile particulate materials is mineral with high contents of uranium such as zircon or apatite in soil. The origins of fissile particulate materials smaller than $25 \mu \mathrm{m}$ may be fragments zircon or apatite and partly responsible to unfissioned fractions of the nuclear bomb. It is important to check physical properties such as the magnetic separation or heavy liquid separation for estimating the origin. For a deposit sample the magnetic and heavy liquid separation were examined, but there were no difference in fission track patterns between ferromagnetic and non-ferromagnetic fractions and between floated and sunk fractions. Then stable elements in a deposit sample were measured by scanning electron microscopy (SEM). However, any elements to estimate the origin were not found around high contents spot of uranium. According to a computer simulation, particle size of $25 \mu \mathrm{m}$ shows the peak position of $13 \mu \mathrm{m}$ as shown in Fig. 9. Taking the length of the fission track on mica into account, it is difficult to determine the diameter for particle with a diameter of smaller than $30 \mu \mathrm{m}$. As mentioned above, the origins of fissile particulate materials could not be clarified. However it should be emphasized that seasonal variation of the concentration of 
elements determined by INAA and the number of star FT are similar to that of influence of Kosa. On addition to this, the Kosa may contain fissile materials as remnant fissile particles from nuclear test site Lop Nor, because the number of star FT was not related to that of homogeneously distributed fission tracks. As far as the present experiment shows, one of the origins of fissile particulate materials is presumed to be due to a random transport of zircon or apatite fragments and in spring the increase of number of them seems to be due to the influence of the Kosa which might contain remnant fissile materials in addition to small fragments of zircon or apatite.

\section{Conclusions}

(1) Probability of the month having higher number than the mean of monthly number of star FT varied in the seasons with a tendency to be larger during December to March.

(2) The diameters of some fissile particulate materials were estimated by comparing with a computer simulation, resulting in approximately several ten $\mu \mathrm{m}$. Many fissile particles smaller than several ten $\mu \mathrm{m}$ were observed, but it was difficult to estimate their diameter for the reasons that the length (about $11 \mu \mathrm{m}$ ) of fission tracks on mica is too long to determine a particle diameter and the number of tracks was too small. It is difficult to determine the diameter for particle with a diameter of smaller than $30 \mu \mathrm{m}$. The method of computer simulation to estimate particle diameter can not be applied to the sample of which the density of tracks in a concentric area is too dense or too thin, because of difficulty to count tracks and larger counting error, respectively. In those cases the time of neutron irradiation should be changed so that the track density is approximately $30000 /$ $\mathrm{mm}^{2}$ at the highest counts in a concentric area.

(3) Although there are different origins such as soil near sampling site and the Kosa, it was very difficult to quantitatively determine those influences in this experiment.

\section{Ackowledgment}

We are grateful to Prof. K. Tomura, Rikkyo University, for using TRIGA-II reactor. We thank Mr. K. Kato and Mr. H. Habuki, Niigata Health Environmental Science Institute, for sending useful references and Mr. S. Komatsu, Seiko EG \& G, for SEM measurement. Thanks are also due to Dr. H. Higuchi, Japan Chemical Analysis Center, for valuable discussions.

\section{References}

1) Igarashi, Y., Otsuji-Hatori, M. and Hirose, K.: Recent deposition of ${ }^{90} \mathrm{Sr}$ and ${ }^{137} \mathrm{Cs}$ observed in Tuskuba, J. Environ. Radioact., 31, 157-169 (1996)

2) Hashimoto, T., Sugiyama, K., Kudo, H., Okada, T. and Sotobayashi, T.: Determination of fissile materials in highly radioactive particles using a solid-state track detector method, J. Radioanal. Nucl. Chem., 100, 135-145 (1986)

3) Hashimoto, T. and Okada, T.: Induced fission track distribution from highly radioactive particles in fallout materials, Houshasen, 13, 32-41 (1987) (in Japanese)

4) Otoshi, T.: Research on monitoring of aerosol in air by neutron activation analysis, $\mathrm{Ph}$. $\mathrm{D}$. Thesis, Rikkyo University (1992) (in Japanese)

5) LLRL: Uranium and thorium isotopes in the precipitation, Low Level Radioactivity LaboratoryKanazawa University, LLRL-AR-16, 5 (1993) (in Japanese)

6) Kadowaki, S.: Size distribution for and concentration ratio between silicon and aluminium in atmospheric aerosols, Nihonkagakukai shi, 12, 1911 -1916 (1977) (in Japanese)

7) Carter, M. W. and Moghissi, A. A.: Three decades of nuclear testing, Health Phys., 33, 55-71 (1977)

8) Al-Najjar, S. A. R. and Durrani, S. A.: Track profile technique (TPT) and its applications using CR-39. I: Range and energy measurement of alpha-particles and fission fragments, Int. J. Radiat. Appl. Instrum., 8, 45-49 (1984) 
9) Dwivedi, K. K.: Reproduction of the observed fission track distribution curves by calculation, Int. J. Radiat. Appl. Instrum., 15, 361-364 (1988)

10) Laichter, Y. and Shafrir, N. H.: Range determination of individual ${ }^{252} \mathrm{Cf}$ fission fragments in solids and gases, Nucl. Phys., A371, 45-67 (1981)

11) Laichter, Y. and Shafrir, N. H.: Fine structure in the stopping powers and ranges of fission fragments in matter, ibid., A394, 77-86 (1983)

12) Zimmerman, D. W.: Uranium distributions in archeologic ceramics-dating of radioactive inclusions, Science, 174, 818-819(1971)

13) Hashimoto, T., Sato, K. Katayama, H. and
Okada, T.: Presence of residual micro hotparticles derived from nuclear explosion events in rain and snow samples, International Congress of Acid Snow and Rain, Niigata, ICASR '97 proceedings (1997)

14) Tanaka, S., Tajima, M. and Hashimoto, Y.: Variation of chemical composition of the atmospheric aerosol in Japan by Kosa phenomenon, Nihonkagakukai shi, 5, 713-719 (1986) (in Japanese)

15) Kawase, K., Kobayashi, U., Koyama, S. and Takizawa, Y.: "Environment and Radioactivity", Tokai University press (1971) (in Japanese)

要旨

\title{
新潟において採取した降下じん埃中の粒子状核分裂性物質の季節変動
}

佐藤兼章, 橋本哲夫*, 野口正安, 真田哲也, 佐藤昭二, 岡田建紀*

\author{
(財)日本分析センター \\ 263-0002 千葉市稲毛区山王町 295-3 \\ *新潟大学理学部 \\ 950-2181新渴市五十嵐二の町 8050
}

1985-1996年の12年間，新潟で毎月採取した降下じん埃中の粒子状核分裂性物質をフィッション トラック法で検出し，その数の季節变動を調べた。粒子状核分裂性物質の数は12月から4月にかけ て多い傾向を示した。その原因を明らかにするため, 降下じん埃中の $\mathrm{Al}$ を含む 10 個の安定元素 を放射化分析法により定量し，粒子状核分裂性物質の数との相関等を調べた。さらに，粒子状核分 裂性物質の粒径をコンピュータシミュレーションにより推測した。それらの結果を踏まえて12月か ら 4 月にかけて粒子状核分裂性物質の数が多くなる原因を考察したところ, 主に周辺環境の土壌之 黄砂による影響であると考えられた。 